Faculty of Law

Faculty Publications

Legal Education at the Crossroads

Supriya Routh

2009

Permission granted by

(C)2009 The W.B. National University of Juridical Sciences, Kolkata

Citation for this paper:

Routh, S., (2009). Legal Education at the CrossRoads. Journal of Indian Law and Society, 1, 58-85. http://jils.co.in/wp-content/uploads/2019/04/supriyo-routh.pdf 


\section{Legal Education At The Crossroads}

SuPRIYA ROUTH*

Unlike the prevalent discussion in the established scholarship associated with legal education, this article presents an alternative to the prevailing notion of the 'Legal Education'on the whole. The present discussion reviews different aspects of legal education for example pedagogy, curriculum design and institutional framework. It further argues that since its inception, legal education in India has been catering to the needs of a particular classification of lawyers and not the legal profession in general. In order to substantiate its position, this article further traces the evolution of legal education in India through various stages while analyzing the approach adopted by the different Government appointed committees has been very much limited due to the political considerations and lack of vision. Also there have been problems associated with the institutional framework of legal education as autonomy and conservative regulation has been major hindrances in the evolution of "Legal Education" to its desired levels. This article suggests that a way forward after the initiation of National law Schools needs to happen otherwise the vision and all the endeavours behind the setting up of the National Law Schools, for example the introduction of multi disciplinary approach towards studying law with the introduction of social sciences and case-discussion model in law subjects might all remain a futile exercises without achieving its purposes. This discussion apart from upgradation of infrastructure and revision of curriculum design further urges the policy makers, academicians and the members of the legal profession to address the issues raised through this article and to broaden the horizon of legal education.

\footnotetext{
*Assiatant Professor of Law, The W.B. National University of Juridical Sciences, Kolkata.
} 
Let me embark on the task of evaluation of the legal education scenario in India from a very fundamental assertion of what law is, and what is its role in the society. A discussion on legal education is drifting without a sense of the ends it seeks to achieve. The diversity of ideas that have been thrown up through contemporary debates around legal education is a poignant reminder of what needs to be achieved - a major overhaul in the way we think of and institutionalize legal education across India. Such debates, occasionally informal but mostly formal, carried out in classroom spaces, faculty seminars and processed through committees and commissions, have traversed a whole range of issues in pedagogy, curriculum design, institutional architecture and autonomy. Together, they have sketched out a roadmap for reforms that could serve us well in the future. However, this reforms agenda cannot be complete without imbibing adequate flexibility to suit the context and detail in which legal education is needed and brought to operation. It is going to be the case that a meaningful reforms agenda would require remarkable sensitivity towards diverse practices, ideas as well as competing narratives of law. Borrowing from my association with a major law university, this paper is an attempt to weave together ideologies and experiences to supply a context against which we could weigh our reforms agenda.

Law is a mechanism of social engineering - it is a mean to an end. ${ }^{1}$ Now if law is a mechanism of social engineering then viewing lawyers (or Advocates) as only legal practitioners in law courts would be extremely myopic and overshadow the true nature of law. Of course a lawyer or an advocate's more orthodox role is to plead in a court of law. But that role cannot deny the range of other role either played or could be played by a lawyer; for example, a lawyer is a potential politician (a role significantly played by lawyers throughout the world), community organizer, policy-maker, professor, rights crusader. A lawyers' role in society is multifaceted and boundless.

The legal education system anywhere in the world should have the characteristic features that promotes and inculcates in students the range of skills that is necessary to realize the embracing role of lawyers in the society. What then should a world-class legal education provide for? A world-class legal education system should institute a 'system' that qualitatively and quantitatively caters to the larger role of law in the society.

\footnotetext{
${ }^{1}$ Brian Z Tamanaha, Law As A Means To An End: Threat To The Rule Of Law (2006).
} 
By "qualitative" I mean the quality of students coming out of the law school and working in different capacities. By "quantitative" I mean presence of sufficient number of students in each of the lawyering vocation. In other words, there must be a heterogeneous working population coming out of the law school. Any law school that produces a homogeneous working population can never claim to be promoting the legal education scenario or catering to the gradual upliftment of the overall legal education scenario. All the great law schools in all ages and locations are testimony of the above fact. All the law schools and the legal education systems having a claim on greatness produces a variety of professionals catering to a range of vocations on a regular basis. This variety is the result of indepth examination, appropriate planning and honest execution.

If the abovementioned are the basis of a world-class legal education system, how many Indian law schools can lay claim to that class? Does the legal education system in the country come anywhere closer to that class?

The law schools as individual units and the legal education system as a whole in the country comes nowhere close to the elite league of world's legal institutions and legal education systems. Moreover, if one takes into consideration the variety of law colleges, university law departments, national law schools and all other law institutions one would conclude that law is taught in an extremely hap-hazard manner in the country - previously, it was one of the most neglected branch of study and now, after the mushrooming of the private law schools, it has become a business with low investment and high returns. ${ }^{2}$

Great lawyers and judges around the world, astute politicians, social activists, brilliant academics, diplomats and lobbyists are product of the legal education system of the country. These people achieved greatness not because of the legal education system, but by their own initiative and zeal. The "system's role" is only marginal and cursory in

${ }^{2}$ The Yash Pal Committee in its report though mentions of such colleges and institutions in engineering and management, but falls short in identifying such law colleges established for business. See, The Committee to Advise on Renovation and Rejuvenation of Higher Education 5 (2009) available at www.academics-india.com/Yashpal-committee-report.pdf. 
their personal endeavor. It is not because of the legal education system, but in spite of it that these people have succeeded. ${ }^{3}$

\section{What IS Wrong?}

Prof. Upendra Baxi remarked in 1975:

"It is simply not possible to think of "modernizing" the syllabi or infusing them with social relevance (and these two are not identical objectives by any means) without an inter-disciplinary or at any rate multidisciplinary awareness. "4

Knowledge Commission in 2008:

"The curricula and syllabi must be based in a multidisciplinary body of social science and scientific knowledge. Curriculum development should include expanding the domain of optional courses, providing deeper understanding of professional ethics, modernizing clinic courses, mainstreaming legal aid programs and developing innovative pedagogic methods. Legal education must also be socially engaged and sensitize students to issues of social justice."

Did we take a single step forward? Both the Reports at a gap of four decades are couched in aspirational terms. One of the principal problems with the legal education scenario in the country is not substantive, it is procedural and psychological. Despite the Committee and Commission Reports, Law Commission Recommendation, Supreme Court insistence hardly has the legal education scenario improved, because who can act choose not to act. There exists a peculiar mind-block in favour of status quo howsoever ineffective and failed the status quo is. The other block in favour of status quo is inaction due to lack of initiative. Because of these basic problems the 70s activism did not fetch much, and it remains doubtful as to how far would the 2000 s initiative go.

\footnotetext{
${ }^{3}$ Upendra Baxi, Notes Towards A Socially Relevant Legal Education in TowARDS A Socially Relevant Legal Education 5 (1979) available at www.ugc.ac.in/pub/ report/1.pdf.

${ }^{4} I d$.
} 
One of the very basic substantive problems is the determination of the nature and purpose of legal studies. The way it is argued and pursued as to whether law is a professional course of study or an academic discipline, there seems to be an apparent conflict between the two propositions. ${ }^{5}$ The debate apparently seems to be tilted in favour of viewing law as a professional course of study. This is clear from the fact that the Bar Council of India is the most significant 'body' in the legal education sphere. They determine the rules of the game and decides what would be taught and to what extent it would be taught as part of the law degree. A perusal of the compulsory courses prescribed by the BCI would further reinforce the 'law as profession' belief. In doing so they substantially narrow down the scope of legal education as a whole, and ends up with a halfhearted measure that neither produces the best lawyers nor creates lawyers who can be instrumental in social engineering.

\section{A. Curriculum Of The Law School}

BCI prescribes the syllabus for the LL.B. degrees (both for 3 years' and 5 years' integrated LL.B.). The LL.B. curriculum can broadly be divided into Compulsory Subjects and Optional Subjects. Compulsory subjects have the further variation of Theoretical papers and Clinical Legal Education.

The BCI Rules on "Standards of Legal Education and Recognition of Degrees in Law for admission as advocates, 1998" prescribed in pursuance of the Advocates Act 1961 has recently been replaced by the "Rules on Standards of Legal Education and Recognition of Degrees in Law for the purpose of enrolment as advocates and inspection of Universities for recognising its degrees in law, 2008". Thus, the BCI regulates the standards of legal education for only would be enrolled advocates, and they (BCI) are the sole Body to regulate (including prescribing legal educational standards and the curriculum) legal education in the country. Hence the premise of the legal education scenario in the country is based on extremely myopic considerations emanating from perceiving legal education as generating court practitioners only. Such an

\footnotetext{
${ }^{5}$ At a later stage of the paper I would argue that there is no conflict between the two propositions and they can harmoniously coexist. Such coexistence would however, depend upon the fact as to how the legal education system is planned and executed.
} 
outlook is evident from the compulsory curriculum prescribed for the LL.B. degree. ${ }^{6}$ Though the Rules (including the nomenclature) have been repealed in 2008, hardly has anything changed from the previous Rules so far as the curriculum is concerned. There still is the compulsory requirement to study 20 subjects focused on different branches of law, giving an impression of mutual exclusiveness of each of these subjects. The overall emphasis of study in each of these courses is positive law and its different legalistic interpretation given by the courts. The interdisciplinarity and multi-disciplinarity is buried under the weight of the compulsions imposed by the BCI. The focus of legal education regulated by the BCI purports to inculcate the overview of all these compulsory papers to the students, rather than instilling research skills and jurisprudential understanding of the "is" and "ought" of law.

Reducing the number of compulsory course requirements and thereby increasing the optional courses would lead to a 'crossing' wherefrom students can steer their career in different directions, rather than the present 'unidirectional highway' they are made to walk. I revert back to this issue sometime later in the paper.

${ }^{6}$ The 1998 Rules provided for the following compulsory subjects: Jurisprudence, Contract I \& II, Tort and Consumer Protection Laws, Family Law I \& II, Law of Crimes, Cr P C, Juvenile Justice and Probation of Offenders Act, Constitutional Law, Property Law, Law of Evidence, CPC and Limitation Act, Legal Language/ Legal Writing Including General English, Administrative Law, Company Law, Human Rights and International Law, Arbitration, Conciliation and Alternate Dispute Resolution Systems, Environmental Law, Labour Law, Interpretation of Statutes, Land Laws.

The 2008 Rules provides for the following compulsory subjects: Jurisprudence, Law of Contract, Specific Contract, Tort including MV Accident and Consumer Protection Laws, Family Law I \& II, Law of Crimes, Cr P C, Constitutional Law I \& II, Property Law, Law of Evidence, CPC and Limitation Act, Administrative Law, Company Law, Public International Law, Principles of Taxation Law, Environmental Law, Labour \& Industrial Law I \& II.

${ }^{7}$ I am particularly tempted to look at the United State's legal education framework, wherein only 5 to 6 law courses are prescribed as compulsory papers, thereby leaving larger part of the degree programme flexible, enabling students to choose from a variety of legal, non-legal and socio-legal courses to choose from. Such a legal education framework produced lawyers, academics, judges, activists, government servants and presidents no less than any other legal education system has produced - definitely not less than the Indian legal education system has produced. 
A perusal of the clinical legal education as it exists today would suggest that the "clinical" or "practical" instruction is only an extension of the classroom teaching, and not practical in any real sense of the term. ${ }^{8}$ There requires to be a six months practical training on the four clinical compulsory courses prescribed by the BCI. A closer look at the BCI syllabus for these papers would suggest that most of the papers are actually not designed to give students the required experiential learning opportunity. The curriculum only becomes an extension of the classroom teaching component. Students actually don't have to do anything by themselves they are to be observers in most of the cases. This is however, except for the paper on 'Public Interest Lawyering, Legal Aid and Para-Legal Services'. That is the only practical where the students are expected to 'practically' do something.

The BCI syllabus on practical papers is fractured and compartmentalized-most of which is taught in the classrooms like other substantive law classes. A much better job can be done by the universities and the law schools with the practical papers if a holistic and purposive view of the same is taken. I also intend to visit this issue later in the paper.

\section{B. Teaching Pedagogy}

When the global legal education scenario debates whether the Socratic 'case-dialogue' method of law teaching is worth the importance it is given, ${ }^{9}$ Indian legal education scenario overwhelmingly trusts the lecture-method imparting 'provision-ingredients' knowledge of law.

The law teacher (in the majority of law schools in India) would come in a class and base her lecture on the bare provisions of law supplemented by the decided cases of the Court of Records (ratio decidendi and obiter dicta, without ever discussing the 'why' element of the decision). The classroom lacks any kind of discussion, analysis and understanding of the range of other variables that operates on the positive law.

\footnotetext{
${ }^{8}$ Supriya Routh, Providing Legal Aid: Some Untried Means 50(03) Journal of INDIAN LAW INSTITUTE 375-390.

${ }^{9}$ For a very interesting discussion on the law school 'case-dialogue' pedagogy and it's limited effectiveness, see generally William M. Sullivan, Anne Colby, Judith Welch Wegner, Lloyd Bond \& Lee S. Shulman, Educating Lawyers Preparation for the Profession of Law 47-86 (2007).
} 
The question papers are testimony of the pedagogy adopted by the different law schools. In majority of the institutions, the end-semester or annual question paper are flat and enquires merely of the different provisions of statutes and case decisions on the subject. The nature of questions lacks any kind of legal analysis or jurisprudential debates. Classroom teaching lacks any kind of innovation, and students' participation is only passive. Hardly do they contribute to the issues under discussion. This fails the very purpose of a higher educational institution, which is generally recognized as generation of knowledge, pooled through different opinions and perspectives.

\section{Law School Faculty}

Competent and committed faculty is another weak link of the legal education system of the country. Admittedly, and sometimes allegedly, many of the faculty members choose to join because law teaching is widely perceived as the least demanding career option. Despite a mandatory minimum entry-level requirement national eligibility test for law teachers, many of the law schools choose to appoint faculties who did not clear the test. This trend, however, is motivated by considerations totally different from each other for law schools situated differently. At times, it is often the case that these minimum entry requirements are not representative of the roles and responsibilities that a law teacher in a present-day law university is expected to manage. Though one agrees that there needs to be some basic minimum requirement for entry into the legal profession, ${ }^{10}$ a good deal of debate needs to happen before we discover these threshold standards. Moreover, these standards are indicative and not determinati ve of the quality of a law teacher. The gap between what the law schools expect, in the quality of their teaching staff, and what they finally get through the current framework of NET, poses a kind of paradox which is deeply troubling for the future of legal education

It may not be far from truth to suggest that academic achievement, rigour, research potential etc are not the only considerations on which a law school is accredited by the main regulatory bodies. There are other

\footnotetext{
${ }^{10}$ Here I want to emphasize a phenomenon that though not directly, but indirectly affect the legal education scenario of the country. A basic minimum entry level requirement is mandated for almost all professions related to law, but strikingly there is no such requirement to enter the Bar and practice law in the courts.
} 
considerations and these are well-reflected through the number of law schools in the country that get the Bar Council of India's recognition despite poor academic and infrastructural standing. In most of such cases, these are schools where "trusts" are the garb of business and profit. Many of these law schools employ people who did not clear the threshold test to become a law teacher. This is often a strategic ploy to pay these law teachers as less as they can and squeeze as much work as possible, both through teaching commitments and administrative obligations, Because of the inherent insecurity about their tenure, these teachers can hardly speak or protest, thus making legal education the biggest loser. As a consequence hereof, it is difficult for these teachers to manage well with these different responsibilities.

On the other hand, excellent institutions with demonstrated academic achievement, appoint extraordinary teachers who did not clear the threshold test. Most of the world renowned legal academicians that the country has today never cleared any threshold test to become a law teacher. ${ }^{11}$ Thus, for people who have authored influential books, or proved their brilliance in their teaching, the formal threshold can hardly hold any significance. But use of the same mechanism to subvert a regulation while at the same time upholding its essence and spirit is problematic and dilutes the very mandate of the regulation in the long run. ${ }^{12}$ It needs to be strictly taken care of that the sole consideration for appointing law teachers who did not clear the threshold test is teaching and research, and not any other extraneous consideration.

Whereas teaching and research are to be the determining criterion of a good faculty, we adduce overwhelming importance to the classroom teaching. This, to a great extent, acts as an impediment to the idea of generating knowledge within a university. Granted that teaching is the most important function of a teacher, but an academic's worth is justified by the research that she engages herself in. It is time to realize that none of these

\footnotetext{
${ }^{11}$ For most of this lot there was no mandate of clearing a test before they ventured into legal academia.

${ }^{12}$ Referring to the trend common in a few national law schools, wherein it becomes imperative to relax the minimum entrance regulations to attract bright and promising teaching staff. At the end, it becomes obvious that the essence of this regulation (which is to ensure a minimum standard of teaching) is realized more through its violation.
} 
aspects run contrary to each other and equal space must be carved out in pursuit of both good teaching and research. Thus, there needs to be an adequate scheme of incentive and disincentive. Apart from the regular refresher programmes, there needs to be faculty development programmes.

\section{Institutional Autonomy}

In most part India's law schools ${ }^{13}$ are generally parts of a university - a department in a university or a college under a university. The national law universities are the only dedicated universities of law. In all these places exists a hierarchiezed decision making process that gives least importance to the people who are actually performing the job on a day to day basis. Learned judges, learned advocates, learned politicians, who have grayed long back decides the goals and modus operandi of legal education in the country. Sometimes, however, some legal academicians are also given a say in some of these decision making committees. People who would implement a policy is given the status of instructors - who would just follow the orders - convinced or not. There is hardly any autonomy at the law school level. At each and every stage one needs to take down what is given. The curriculum is determined by the BCI, the budget is determined by the funding bodies (or for self financing institutions, their corpus), how to spend the budget is determined by the Executive Council or the Finance Committee of a university. The faculties, the students or educators would have no say in these matters. The Committees that decides these issues often operate on diverse considerations extraneous to welfare of the legal education system. However, allegation of lack of autonomy would be somewhat misplaced for national law schools. The Vice Chancellor is the single most powerful person in the national law schools life, despite the presence of the different policy determining Committees.

\section{A Renewed InITIATIVE}

The $21^{\text {st }}$ Century ushered in new challenges, novel perspectives and greater opportunities for legal education in the country. As a result the new century brought an unprecedented activism in the legal education scenario in particular and the overall higher education scenario in general in the country. Beginning from the $184^{\text {th }}$ Report of the Law Commission

\footnotetext{
${ }^{13}$ I am using the general term "school" as a generic substitute for all the other formations, i.e., college, department, institution, academy etc.
} 
of India there has been three other initiatives in the sphere of legal education and the overall higher education in this decade, the latest of which being The Committee to Advise on Renovation and Rejuvenation of Higher Education, more popularly known as the Prof. Yash Pal Committee Report. Though there have been incremental approaches to improve the legal education scenario in the country, what is significant for the reports prepared in the present decade is their approach of taking a holistic look at the legal education scenario of the country. I don't wish to burden this section with what each of the Committees have to say, but I do want to take a look at their approach and suggestions in the present context. I focus my attention specifically on the recent reports. ${ }^{14}$ However occasionally I will go back to some of the earlier Committees so far it relevant for the present discussion.

The $184^{\text {th }}$ Report was technically termed as: The Legal Education and Professional Training and Proposals for Amendments to the Advocates Act 1961 and the University Grants Commission Act, 1956. One would have expected a broader understanding and interpretation of "legal education and professional training" from the Commission than they have actually come up with. The report though paid lip service to every aspect of the legal education system in the country, the overwhelming (and to a great extent, the only) purpose of the Report was to attune legal education in the country to the necessities of the Bar. With an attempt to justify the overwhelming significance of the report prepared, the Committee heavily resorted to the erstwhile attempts to improve and revive the legal education system. While such a phenomenon goes on to point out the open-minded approach of the committee, it also suggests inaction on the part of the implementing agencies for a long time. Since, most of the previous initiatives were not acted upon, those still constituted "novel" suggestions to improve the scenario. The Report of the Commission was myopic to the extent of its concentration on legal education only from the court practitioners' point of view. Within the limited focus of its operation, the Commission however, came up with significant recommendations that would go a long way to uplift the education system. One of the prime point of the Commission's recommendation is the constitution of a committee by the University Grants Commission (UGC). This committee would be a representative committee of the Universities imparting legal education, which would make

\footnotetext{
${ }^{14}$ I thereby exonerate myself from looking into the pool of other reports purported to improve the legal education scenario in the country.
} 
representation to the $\mathrm{BCI}$ in matters of legal education. ${ }^{15}$ Constitution of a Legal Education Committee of the BCI had also been by the Report to facilitate meaningful discussion with the other committee (UGC Committee) and regulate and "standardize" legal education in the country. The Commission took some time to explain the significance of alternative dispute resolution mechanisms and proposed its compulsory inclusion in the law syllabus. While recommending compulsory inclusion of the clinical method of legal education the Commission throws its weight behind the problem-method of law teaching. To facilitate pedagogic innovation and teaching skills the Report recommended establishment of law teachers' training institutes in the country. As part of same agenda the Commission promoted the idea of involving more and more adjunct teachers in regular law teaching in the universities. This was seen by the Commission as an initiative capable of improving teaching of law. BCI was called upon to cautiously approve and recognize new law teaching institutions, and they were also urged to make compulsory a one year training programme for all law graduates before they could join the Bar. Here one must note that the entirety of the BCI proposals was based on the "Report of The Task Force on Law Schools and the Profession: Narrowing the Gap", formally titled "Legal Education and Professional Development -An Educational Continuum" (more popularly known as the MacCrate Report, on the Chairperson's name) prepared by the Legal Education and Admissions to the Bar section of the American Bar Association.

MacCrate Report was prepared to bridge the "gap" between practice of law in the court and legal education at the universities. ${ }^{16}$ It did not take a holistic view of legal education for the purpose of satisfying the

15 The Commission also suggested amendments to the Advocates Act, 1961 and the University Grants Commission Act, 1956 to make this mechanism possible. See, Law Commission of India, 184th Report on The Legal Education and Professional Training and Proposal for Amendments to the Advocates Act, 1961 And the University Grants Commission Act, 1956 (2002) available at http:// lawcommissionofindia.nic.in/reports/184threport-PartI.pdf.

16 "It has long been apparent that the American law schools cannot reasonably be expected to shoulder the task of converting even very able students into fullfledged lawyers licensed to handle legal matters. Thus, a gap develops between the expectation and the reality, resulting in complains and recriminations from legal educators and practicing lawyers. The lament of the practicing bar is a steady refrain: "They can't draft a contract, they can't write, they've never seen a summons, the professors have never been inside a courtroom." Law schools offer the traditional 
needs of the society outside the courtroom - their terms of reference were very narrowly construed. ${ }^{17}$ Having such an unidirectional objective at the back of their mind the Task Force came up with "The Statement of Fundamental Lawyering Skills and Professional Values" 18 for lawyers. The Statement lists the fundamental lawyering skills as: problem solving, legal analysis and reasoning, legal research, factual investigation, communication, counseling, negotiation, litigation and alternative disputeresolution procedures, organization and management of legal work and, recognizing and resolving ethical dilemmas. ${ }^{19}$ The identified professional values were: provision of competent representation, striving to promote justice, fairness and morality, striving to improve the profession and, professional self-development. ${ }^{20}$ Though these skills and values are essentially projected as lawyering skills from the practitioners' point of view, many of the components so identified are essential for the variety of law professions other than a practicing lawyer.

responses: "We teach them how to think, we're not trade schools, we're centers of scholarship and learning, practice is best taught by practitioners."

However, the Report asserts that there is no "gap" between the law school education and the legal profession: "[W]e have concluded that there is no "gap". There is only an arduous road of professional development along which all prospective lawyers should travel. It is the responsibility of law schools and the practicing bar to assist students and lawyers to develop the skills and values required to complete the journey."

See Section of Legal Education And Admission To The Bar- American Bar Association, Legal Education and Professional Development - An Educational Continuum, Report of The Task Force on Law Schools and Profession: Narrowing THE GAP, 4-8 (1992) available at http://www.abanet.org/leagled/publications/ onlinepubs/maccrate.html.

17 To broaden the perspective on the issue of the preparation of lawyers for practice, a subcommittee of the Task Force conducted four public hearings between February 1990 and June 1991. Participants in the hearings were asked their opinion: on whether newly admitted lawyers were prepared to practice law without supervision; as to what should be taught to improve graduates for practice; on how any additional training, if desirable, should be accomplished; and whether they favored a skills training requirement and performance testing for bar admissions.

See Id. at xii.

${ }^{18} \mathrm{Id}$. at 135.

${ }^{19} \mathrm{Id}$. at $138-207$.

${ }^{20} I d$. at $207-221$. 
A far more balanced Report (and a far more relevant Report from Indian legal education perspective) was the Report prepared by the Carnegie Foundation for the Advancement of Teaching in 2007. The Report is technically termed: Educating Lawyers - Preparation for the Profession of Law (popularly Carnegie Report). Appraising us of the nature of law schools the Report observes:

"Like other professional schools, law schools are hybrid institutions. One parent is the historic community of practitioners, deeply immersed in the common law and carrying on traditions of craft, judgment, and public responsibility. The other heritage is that of the modern research university. These two strands of inheritance were blended by the inventors of the modern American law school, starting at Harvard in the 1870s." 21

Beginning from such a premise the Foundation took upon itself the task of providing the merger of these two goals of the law schools in the best possible way:

"We are convinced that this is a propitious moment for uniting, in a single educational framework, the two sides of legal knowledge: (1) formal knowledge and (2) the experience of practice. We therefore attempt in this report to imagine a more capacious, yet more integrated, legal education." 22

Such a merger of professional educational goals with that of the academic disciplinary goals should result in three broad elements for the law school curriculum. The three-pronged approach of the law schools should constitute of teaching of legal doctrines and analytical skills, inculcation of lawyering skills and ethics, and orientation on the fundamental principles, purposes and values of the profession of law in the society ${ }^{23}$.

The next initiative to improve the legal education scenario in the country came in the form of the National Knowledge Commission (in

\footnotetext{
${ }^{21}$ Sullivan supra note 9 , at 4.

${ }^{22} \mathrm{Id}$. at 12 .

${ }^{23}$ Id. at $194-202$.
} 
short, the Commission), constituted by the Prime Minister, which submitted it report on legal education in $2007 .{ }^{24}$ The Commission constituted a Standing Committee for Legal Education to take an in depth look at the issues and challenges of legal education in the country. The Commission recognized "legal education as an important constituent of professional education". ${ }^{25}$ Thus, the legal education construct, as identified by the Commission is "professional education". Such a construct would determine the discourse of legal education that the Commission sought to steer forward. There is, however, a problem with such a construct of legal education. In formulation of such a construct of legal education the commission does not view legal education as an academic discipline, or knowledge generating field - to them the legal education discourse is a professional educational endeavor. They are, however, aware, unlike the Law Commission, that such a professional educational endeavor needs to produce not only practicing lawyers but also academics, legislators, judges, policy makers, civil society activists etc.

Identifying the purpose of legal education as incorporating spirit of public service and emphasizing on legal research to create new legal knowledge, the essence of the commission proposal was modernization of the law curriculum. Such modernization initiative, on one hand, needs to have a multidisciplinary and comparative curriculum, on the other hand such education must be socially engaged. Apart from the doctrinaire analysis-based classroom law teaching, the Commission emphasized on clinical legal education, especially to deliver justice to the poor apart from educating the students. To attain these ideals the Commission appropriately emphasized on the two-prong infrastructural development of the law

\footnotetext{
${ }^{24}$ The National Knowledge Commission ("NKC") was established by the Prime Minister of India in 2005 to recommend and undertake reforms in order to make India a knowledge-based economy and society. In the Prime Minister's words: "The time has come to create a second wave of institution building, and of excellence in the field of education, research and capability building." As part of the Commission a Working Group on Legal Education had been constituted. See National Knowledge Commission, Report of the Working Group on Legal EDUCATION (2007) available at http://knowledgecommission.gov.in/downloads/ documents/wg_legal.pdf.

${ }^{25}$ See National Knowledge Commission, Report to the Nation 2006-2009 79 (2009) available athttp://www.knowledgecommission.gov.in/reports/report09.asp.
} 
schools; one, law school resources in terms of the library, use of technology, and second, law school resources in terms of appointing and retaining competent faculty. The Commission did spend adequate time to think of the law faculty. While emphasizing on the research culture in the law schools and the faculty, they proposed right to practice, and other consultancy privileges for the law faculties in addition to the teaching job. The Commission did this based on an understanding of the salary differentiation amongst different law professions. ${ }^{26}$ The other substantive proposals related to the improvement of the teaching pedagogy and examination system, which the Commission proposed to be 'problem-based'. The Commission proposed the reintroduction of the Bar Examination to improve the quality of legal practitioners in the country.

The Commission vehemently argued for institutional autonomy and reduction of the role of the $\mathrm{BCI},{ }^{27}$ specially with matters of curricula and syllabi. While proposing a very marginal role for the $\mathrm{BCI}$ the Commission recommended a new regulatory mechanism for legal education - a Standing Committee on Legal Education, to be established under the Independent Regulatory Authority for Higher Education (IRAHE) with much wider representation than any other committee had proposed.

Then came the Committee to Advise on the Renovation and Rejuvenation of Higher Education, instituted by the Ministry of Human

\footnotetext{
${ }^{26}$ The issue reminds me of a very informal talk I had with my American supervising professor, Frank Bloch. On being asked why the American law schools pay so much to their faculties, compared to anywhere else in the world. Frank's simple answer was that the law schools see us as otherwise practicing lawyers (through a good practicing lawyer would earn much more), and therefore tries to compensate us at par.

We, however, in India of course don't think that way. Our premise is based on the understanding that law teachers are teachers because they did not have anything else to do, and hence pay them as less as you can.

${ }^{27}$ The Commission has tried hard to break the legal education system free of the shackles of the BCI controlled unidirectional system catering to the needs only of the Bar. It was observed that the BCI is exercising more powers than was intended by the Advocates Act 1961. There is no effective consultation between the faculties and the BCI - there are more than 700 law schools in the country but the faculty has no say in legal education. Moreover BCI has granted permission to law schools that are maintaining very poor standards of legal education (something observed by the Justice Ahmadi Committee, 1994, and reiterated by this Commission.
} 
Resource Development and headed by Professor Yash Pal. The Committee submitted its report in 2009. The Committee began its journey with a fundamental question: what is the role of a university in higher education? Finding that the role of a university cannot be limited to only consumption of knowledge, but also generation of knowledge, not only for the university learners, but for the society as a whole, the Committee came up with a holistic reformation proposal of higher education in the country. The Committee observed that if the principal role of a university is to create new knowledge, the artificial disciplinary boundaries should get blurred at some level. There needs to a multidisciplinary approach for generation of new knowledge. Such multidisciplinarity should not only be there in the syllabi and curriculum, it must also be evident from the university's approach in solving real-life problems in its immediate vicinity, and its initiative to work with other research and academic institutions of a diverse specializations. The Committee came down heavily on the variety of deemed and 'stand alone' universities. ${ }^{28}$ The national law schools are thus at the receiving end of the Committee. If the Committee's recommendation are to mean anything, the national law schools are to diversify their range of subjects in addition to incorporating multidisciplinarity in their curriculum. A perusal of the report would suggest that the premise of the report has been fundamentally academic - to them the role of the university is more of a (inter) disciplinary study than a mere professional school, though generating professionals is one of its ardent duty. In such a context the Committee suggests of higher standard for the stand-alone universities to get approval or recognition as a deemed university. Like its predecessors this Committee was also irked with the role of the different regulatory bodies and Councils. It proposed the abolition of all the Councils (Bar Council of India, Medical Council of India etc.) for regulation of higher education, and suggested one Commission of Constitutional status - the National Commission for Higher Education and Research (NCHER) to regulate higher education in the

\footnotetext{
${ }^{28}$ While commending the role of the IITs and IIMs in the country's development, the Committee suggests these stand-alone universities to diversify their disciplines and increase their role in the overall societal development. It gave example of universities like the Massachusetts Institute of Technology, and CALTECH, which though had a stand-alone beginning now caters to a range of disciplines and is the melting pot of interdisciplinarity. See, The Committee to Advise on the Renovation and Rejuvenation of Higher Education 15 (2009) available at www.academics-india.com/Yashpal-committee-report.pdf.
} 
country. The Committee was of the view that all these Councils end up interfering into the activities and initiatives of the higher educational institutions. Such a phenomenon is wholly undesirable. Autonomy of the universities in its policy determination, curriculum delineation and improvement should be religiously preserved. Finally, the Committee was of the view that there must be an independent evaluation of the performance of the universities on a regular basis, and such evaluation should be the basis of recognition or derecognition of the universities.

\section{Now What?}

The problems have been identified, solutions prescribed, but then what? Someone needs to act now. But can we be hopeful considering the number of committee reports that has been submitted so far, and the extent of inaction those are met with. ${ }^{29}$ Then there are additional problems of the conflicting recommendations and different approaches taken by the different committees. Whereas on one hand the $184^{\text {th }}$ Report of the Law Commission encourages the national law schools and the like institutions, the Yash Pal Committee vigorously opposes such an idea and recommends diversification of disciplines in every university. The $184^{\text {th }}$ Report of the Law Commission proposes revival of legal education principally from the perspective of the court practitioners. The Knowledge Commission takes a wider approach in terms of the law professionals. But the premise of the Knowledge Commission was based on an understanding that perceived legal education as only a 'professional education' endeavor. There are however, unanimities amongst the different reports on the issue. All the reports of the decade are unanimous that

\footnotetext{
${ }^{29}$ A not so exhaustive list of the Committees would include First INDIA UnIVERSITY Commission Report 1902; Report of the Chagla Committee, 1955; Report of the Bombay Legal Education Committee; Report of the Inter-University Board, 1950; Report of the All India Bar Committee, 1953; Report of the Rajasthan Legal Education Committee, 1955; $14^{\mathrm{TH}}$ Report of the Law Commission, 1958; Recommendations of the Gejendragadkar Committee, 1964; Formulations of All India Seminar on Legal Education, 1972; Towards a Socially Relevant Legal Education - A Consolidated Report of the University Grant Commission's Workshop on Modernization of Legal Education 1977; UGC Curriculum Development Report, 1988-90; Justice Ahmadi Committee Report, 1994; UGC Curriculum Development Report, 2001.
} 
multiplicity of regulatory mechanism seriously disturbs the academic environment of the law schools. The BCI has over lived its life so far as determination of the legal education policy of the country is concerned. The Council should only regulate the entry into the Bar for practicing lawyers. Accordingly suggestions have been put forth for the amendment of the Advocates Act and the University Grants Commission Act. From amongst such a web of recommendations and counter-recommendations, proposals and counter-proposals arises the difficulty of choice. So previously we had one problem, and that was of inaction; now we have two, inaction coupled with the difficulty of choice.

With regard to the first problem I stand nowhere to correct; if I were I would not have been writing this paper. With regard to the second part of the problem, if one is to formulate a course of action what would it be? I here take the onus on myself to delineate a course from amongst the web sketched above.

To me legal education is not 'only' a 'professional education'; neither is it 'only' a 'disciplinary education'. It is a fine blend of 'professional' and 'disciplinary' education, resulting in a tentacle extension of each one into the other. An advocacy for a group of contract workers would require sound 'professional' knowledge of the Contact Labour (Regulation and Abolition) Act for the ascertainment of the rights and liabilities of the various parties; the Industrial Disputes Act for the ascertainment of the appropriate tribunal; the Civil Procedure Code for the rules of drafting and conveyance; actual drafting of petition; fact-finding; counseling; ethical dilemmas and decision making etc. But such 'professional' knowledge would be incomplete (and hollow) without a solid grounding on the Theory of Justice, Role of Welfare State, Constitutionalism and the law and development movement. This was just a rough example to establish my stand - it can separately be developed as an argument for another paper. I therefore would like to begin from where the Carnegie Foundation did. A blend of professional and academic legal studies must have a three pronged approach: (i) teaching of legal doctrines and analytical skills; (ii) imparting of lawyering skills and ethics; and (iii) orientation on the fundamental principles, purposes and values of the profession of law in the society. ${ }^{30}$ Placing these three elements in the

${ }^{30}$ SulLivan supra note 9, at 194-202. 
law school context would need elaboration as to what does it mean for the curriculum of the law school, teaching pedagogy adopted to execute the curriculum, role and responsibility of the faculty, and infrastructure and autonomy of the law school. I accordingly deal with each one of these in the following paragraphs.

\section{A. Curriculum Of The Law School}

One of the first things that need to be done with regard to the curriculum in the law school is to reduce the number of compulsory courses. Reduction in the number of compulsory courses would give more flexibility to the school to integrate interdisciplinarity and multidisciplinarity in its curriculum. We as a legal-education-community need to shift our understanding of the nature of law teaching. The crux of legal education is not to impart knowledge of as many provisions as one can. The quest should rather be on 'how and where to find the law'; 'how to analyse the law and apply it in the appropriate context'. Such an understanding would help us streamline the compulsory courses and leave more scope to multidisciplinarity in legal education. The existing syllabus prescribed by the BCI does pay some lip-service to interdisciplinarity by incorporating some social science papers in the law school curriculum. These papers are, however, taught in the first two years of legal education and are taught in an extremely abstract manner. The popular notion amongst the law students is to somehow 'clear' these social science papers in the first few semesters, and that these have no role in the actual study of law. One way to address the issue is to teach the social science papers in such a way that makes their relation with law explicit. This can be done either by the teachers themselves, or innovative changes could be brought in within the syllabus. Another way may be to teach these subjects jointly by a social science teacher and a law teacher, wherein each of them could bring in new perspectives from diverse fields. Unfortunately the prevalent practice in most of the university based law colleges is to invite faculties from the other disciplines to teach a few classes in social sciences for the law students. Because of the disciplinary limitations these faculties ends up giving narrative overview of the subjects without drawing any link between the subject and legal studies. However, a positive initiative in this regard is taken by the national law schools atleast in appointing full time faculties for social science subjects.

A reduction of the number of compulsory courses would allow more slot for optional and seminar courses. These should be the papers 
that should act as the melting pot of different disciplines. Each law school must therefore devise their own ways to approve of the optional courses to be offered to the students. Constituting a 'Curriculum Development \& Approval Committee' in each of the law schools in this regard should be a worth initiative in itself. This committee should look into the formulation, structure, materials, pedagogy etc. of not only the optional courses but also the compulsory courses and approve them before offering it to the students. There must be periodical review of all these courses offered to the students.

Students should be writing a project paper for the optional and seminar courses; whereas this a feature of the national law schools, most of the law schools throughout the country are indifferent to such an approach.

A progressive legal education system should gradually move from 'only' doctrinaire legal analysis to a more complicated problem-solving approach. The second approach is not devoid of the first one, but incorporated and addresses the complex variables of the society in which law operates. Here lies the significance of clinical legal education. As I have already pointed out that the BCI have four distinct compulsory clinical papers for the first law degree, but the way these papers are 'taught' suggests of no interrelation between these papers, or any other courses studied along with them. These are treated as four distinct papers to be offered during the last two years of the degree.

I argue that instead of serving to the categorical distinction between the practical papers, the law schools should attempt to meet the requirements of the papers by devising a real client clinical structure and placing each of the practical-paper requirements within such structure. To develop the idea further let me use a community development clinic model as example in Indian context. Community lawyering initiative uses legal as well as non-legal mechanisms to attain their goals. It is characterized by collaboration with the client community, partnering with client, networking with individuals and institutions and forming bargaining units, generating political power and plethora of other strategic initiatives. And it is a long term business. In a community lawyering clinic students assist pro se litigants, teach the community, pursue legislative reform and perform a plethora of other conventional and non-conventional lawyering jobs. ${ }^{31}$

${ }^{31}$ Antoinette Sedillo Lopez, Learning Through Service in a Clinical Setting: Te 
All these community lawyering works purported to be done by the students involve the skills that BCI prescribed practical papers intends to impart. But the difference is that instead of being taught in class students learn these skills by working amongst the community and learn by doing it themselves. This would also constitute a significant pedagogic improvement over the case-discussion method or the lecture method that is commonly followed. Such an initiative would also cater to the social justice promotional activities of the law schools. ${ }^{32}$ That takes us to the next issue for consideration.

\section{B. Teaching Pedagogy}

Indian legal education suffers from "narration sickness". ${ }^{33}$ This lecture based narration methodology cripples the legal education system in the country. Such pedagogy is to a large extent an obstacle in any attempt of multidisciplinary approach to legal education. As I have

Effect of Specialization on Social Justice and Skills Training, 7 CLINICAL L. Rev. 311-312 (2001).Also see Katherine R. Kruse, Biting Off What They Can Chew: Strategies for Involving Students in Problem-Solving Beyond Individual Client Representation, 8 CLINICAL L. REV. 405, 408-409 (2002). Kruse argues that the functions performed by the community law clinic students are actually identical to that of the social justice lawyers constantly struggling for the causes of their clients: "These efforts mirror those of legal service providers, who daily confront the challenge of doling out a limited commodity of lawyers to a growing number of poor and socially marginalized persons in need of legal assistance. Through fundraising, activism, triage, heightened caseloads, pro bono networks of volunteer lawyers, and "unbundled legal services" like legal advice hotlines, legal services organizations try to piece together some combination of strategies to reach out to unrepresented persons who desperately need lawyers to handle the most basic of life's problems. "Also see Sameer M. Ashar, Public Interest Lawyers and Resistance Movements, 95 CAL. L. REv. 1879, 1895-1907, 1915-1916 (2007); It is a classic fact of the community lawyering concept that the immigrant worker issues were not resolved by litigation; it was rather solved by outside court settlement effected through the campaigning and other pressures exerted by the "community" of workers.

${ }^{32}$ American Bar Association supra note 16, at 238-245; Sullivan supra note 9, at 120-122; The Committee to Advise on Renovation and Rejuvenation of Higher EDUCATION (2009) available at www.academics-india.com/Yashpal-committeereport.pdf.

${ }^{33}$ Paulo Friere, Pedagogy of the Oppressed (1972). 
argued that a progressive legal education system should gradually move from 'only' doctrinaire legal analysis to a more complicated problemsolving approach. This movement has to be reflected in the teaching pedagogy of the law school. The Langdellian case-discussion model, which is largely followed in the American universities though an improvement over the lecture-method, however aims at imparting only doctrinaire legal knowledge amongst the students. In the case-dialogue method, unlike the lecture-method, the students are not only passive recipients of legal knowledge; they are also active participants in the process of learning. But however, such a method has been criticized as foreclosing reflections from other variables that influences a case decided by a judge. A case decided by a judge at the apex court is taken to be a self-sufficient methodology in itself. This is quite in keeping with Dean Christopher Columbus Langdell's idea of law being a self-sufficient science in itself. The Socratic case-dialogue pedagogy has been found to be quite effective in imparting doctrinaire legal knowledge among the students. On the other hand the pedagogy has been challenged as being incomplete in imparting a complete legal education. Further improvements are suggested over the case-dialogue method of law teaching. Increasingly the problem-solving method is being put forth as an incremental substitute of the case-dialogue method. The problem-solving method involves contextualizing a legal problem in the society, so that it can be studied from as many different perspectives as actually exist in the society. Such a pedagogy recognizes the inclusive nature of legal education and rejects the exclusivity of legal studies. Instead of studying law in a vacuum, the problem-solving method purports to study law in all its complexities. Proponents of this pedagogy claims that it is the most complete form of teaching pedagogy, wherein students are taught to consider all possibilities surrounding an issue. Picking up the issue from here I would suggest extensive use of the clinical methodology of teaching in the Indian law schools. But, I wish to add couple of clarifications to this assertion. When I argue the use of clinical pedagogy of law teaching, I mean "experiential learning" - learning by doing, and not classroom teaching of practical papers. I argue for such a pedagogy in addition to the doctrinaire Socratic teaching of the classroom, and not in exclusion of the same. Such a pedagogic improvement would depend to a great extent on the faculty who are to execute the methodologies; and that brings us to the role and responsibilities of the faculty in the law schools. 


\section{Role And Responsibility Of The Faculty}

Nowhere else is the lack of appropriate and competent personnel felt as much as in the law schools in the country. The country does not produce adequately qualified (not in the degree sense of the term, but in the competence and commitment sense) faculty to serve the needs of 700 odd law schools that the country has. Thus the Knowledge Commission has appropriately identified 'attraction and retention' of competent faculty as one of the basic problems with the legal education system. Under such circumstances the law schools need to have enough flexibility to appoint competent teachers even if they lacks some of the formal criterions to become a law professor. Another deterring factor for brilliant law students not joining the academia is the lack and delay of material benefits that the academia characterizes. However, after the implementation of the Sixth Pay Commission proposals things have improved manifold. There can be further improvements in this regard. Law Schools capable of better funding can think of incentivizing faculties excelling in teaching and research consistently with additional increments over and above the regular scale. I am particularly drawn to a suggestion put forth by Kausik Basu in his dissent on the Yash Pal Committee Report. He suggests 20 universities in the country should be declared as centre of excellence, and therefore should receive better funding to incentivize faculty. There will therefore be an incentive for the faculties to perform better to become part of these universities, and receive better packages. The list of the 20 universities should be periodically undated at regular intervals. For him, the other alternative would be to pay the performing faculties three or four times the regular salary received by any faculty in the same designation. ${ }^{34}$ Though these suggestions were not part of the unanimous view of the committee, can suo motu be acted upon by the universities to incentivize their faculties.

So far was the brainstorming to attract and retain talented faculty. How to improve the present lot, instead to showing them the door. There needs to be regular orientation and workshops for the faculty, in addition to the UGC refresher courses. Such orientations and workshops can

\footnotetext{
${ }^{34}$ Kaushik Basu, Report of the Committee to Advise on Renovation and Rejuvenation of Higher Education in India - A Note of Dissent available at http://prayatna.typepad.com/education/2009/07/full-text-of-kaushik-basusdissent-note-to-the-yashpal-committee-report.html.
} 
either be centralized through the UGC or the law schools can take individual initiative. There can be teacher training institutes also to train law faculties in different pedagogies. ${ }^{35}$

Apart from training the teachers in teaching pedagogy, inculcation of a research culture is the call of the day. Workshops and sessions on research techniques, publication should be regularly undertaken. Teachers should not be overburdened with teaching and other administrative assignments. In almost all the good universities throughout the world, teachers are not required to teach on all 5 or 6 days a week. Each teaching session involves substantial preparation and planning; and this requires quality time. Research, on the other hand involves substantial quality time, and more often than not the researcher needs to be in her elements, secluded from the worries of the teaching session to produce something qualitative. Thus the teaching days in the law schools for each faculty should be reduced to 2 or 3 days. Each of the teaching sessions in these 2 or 3 days can be of 2 to 3 hours, with a 10 minutes intervening break. Such formulation would allow some quality time for the teachers to concentrate in the class and experiment with Socratic and Problem-solving pedagogy; the mechanism would also leave the teacher with ample time to do their own research. Initially teachers might find it difficult to adjust with such a mechanism, but once the shift is made it would go a long way to faculty improvement in the law schools. A popular concern of the 'people in power to implement these changes' (and also some people outside such power framework) with regard to such a mechanism is that the teacher might not use the free time (free of classes) to do research, instead they might engage in other activities unrelated to academics. One needs to understand here that the teachers are not bonded workers, and each and every activity of theirs cannot be controlled. Once they are taking their classes in the present mechanism of 5 to 6 classes of 45 minutes a session, no one can regulate the rest of the hours for the teacher. However, the proposed mechanism along with the incentive for performance would create atleast the minimum

\footnotetext{
${ }^{35}$ Law Commission of India, $184^{\text {Th }}$ Report On the Legal Education and Professional Training and Proposal for Amendments to the Advocates Act, 1961 and the University Grants Commission Act, 1956 (2002) available at http:// lawcommissionofindia.nic.in/reports/184thresport-PartI.pdf.
} 
framework for a better faculty inventory in the law schools. All these proposals would naturally take us to the final issue to be addressed for the paper, i.e., infrastructure of the law schools and its autonomy.

\section{Infrastructure And Autonomy Of The Law School}

To execute some of the abovementioned 'outside the box' proposals and to improve the infrastructure in the law schools, one of the basic precondition is the autonomy of the law school. This is a moot issue where all the erstwhile committees of the decade on legal education are unanimous.

Infrastructure of the law schools are so unevenly distributed across the range of institutions that whereas some of the law schools have multistoried library buildings; some others don't even have their own library; and for some, one medium-sized room makes a mockery of library. All these institutions, however, receive BCI approval, for reasons untenable and inexplicable by a common man's prudence. For some law schools development of infrastructure is a burden in itself, because of paucity of funds. Some trust-based law schools run in such fund crunch that provision for faculty salary also becomes a difficult proposition. Funds need to be pumped in these law schools for the improvement of their infrastructure. Otherwise the students studying in these institutions are the ultimate losers, and the BCI cannot avoid its responsibility of being an active participant in the process.

For law schools that do not fall within the above category, the hurdle is the hierarchized decision making and the lack of autonomy. I have already pointed out the problems with the hierarchized decision making process, hence, I am not repeating myself here. What needs to be done is to allow as much of autonomy to the law schools as is required for the smooth functioning of the law schools. While lack of autonomy is a problem with the university based law colleges and the law departments, it is not so with the national law schools. Perhaps, the national law schools enjoy over autonomy. The national law school mechanism is Vice Chancellor (VC) centric, and the office of the VC enjoys a significant quantum of autonomy than his counterparts in other institutions. Thus, working of the national law schools is dependent essentially on an individual. Since, autonomy vests in one person rather than a group of individuals, the scope of misuse of such autonomy is enormous (because of the simple proved fact that power corrupts, and absolute power corrupts 
absolutely). ${ }^{36}$ Thus while the law schools throughout the country should be allowed more autonomy in their functioning, a single individual-centric power would bring too much of subjectivity in the operation of the schools. Therefore, instead of vesting autonomy on an individual, a far more appropriate approach would be vesting of autonomy to a small group within a university. Representation of the law schools in different education policy determining bodies should not only be made the senior professors, or office bearers of the university or the law school, it should be a mix of teachers from all levels (Assistant, Associate and Professors). While this will ensure a counterbalance against anarchy, it would also bring in new perspectives and diverse reflections for future action.

\section{Concluding Thoughts}

The West Bengal National University of Juridical Sciences Act 1999 in section 4 states its objects:

"The objects of the University shall be to advance and disseminate learning and knowledge of law and legal process and their role in national development, to develop in the student and research scholar a sense of responsibility to serve society in the field of law by developing skills in regard to advocacy, legal service, legislation, law reforms and the like, to organize lectures, seminars, symposia and conferences, to promote legal knowledge and to make law and legal processes efficient instruments of social development, to promote inter-disciplinary study of law in relation to management, technology, international cooperation and development, to hold examinations and confer degrees including joint degrees in law combined with other disciplines and other academic distinctions, and to do all such things as are incidental, necessary or conducive to the attainment of all or any of the objects of the University."

\footnotetext{
${ }^{36}$ The famous quote from John Emerich Edward Dalberg Acton expressed in a letter he wrote to Bishop Mandell Creighton in 1887. I am however, not using the second part of the quote that says: "Great men are almost always bad men".See The Phrase Finder, available at http://www.phrases.org.uk/meanings/288200.html.
} 
I cannot think of any object that the Act might have left outside its statement of object. This, I take as true for almost all of the other law schools established in the country (without any research on the same, though). Thus the inception of the law schools are premised on a broader view of the purpose of legal education. What we need to do is to narrow and eventually obliterate the gap between the objective and its actualization. We need to do this with urgency for the non-elite law schools of the country. Therefore, we have a dual task at hand. On one end we need to narrow the gap between the national law schools and some other first tier non-national law schools on one hand, and the rest of the 650 or so law schools imparting legal education in the country. On the other end we need to continuously strive to bring our legal education at par with the best educational systems in the world. I am particularly tempted to conclude with part of the Foreword observation of the Chairman of the National Knowledge Commission: the exercise is “... really a call to action. It is time to act and implement ...". Is anyone listening? 